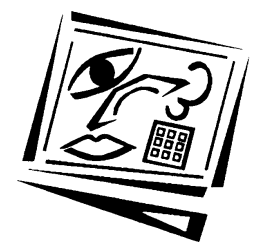

\title{
Developing technological pedagogical content knowledge in pre-service science teachers: Support from blended learning
}

\author{
Ghaida M. Alayyar \\ Public Authority of Applied Education and Training, Kuwait \\ Petra Fisser and Joke Voogt \\ University of Twente
}

\begin{abstract}
The Technological Pedagogical Content Knowledge (TPACK) framework has been used to prepare pre-service science teachers at the Public Authority of Applied Education and Training in Kuwait for ICT integration in education. Pre-service teachers worked in teams to design an ICT solution for an authentic problem they faced during in-school training. Pre-service teachers were separated into two groups. The first group was coached by ICT, pedagogy, and content experts. The second group was offered a blended condition, by which they had access to an online portal with different tutorials and examples, with opportunities to meet with different experts whenever they wanted. Pre-test and post-test design data were collected for attitudes toward ICT, ICT skills, and TPACK. The findings show that the self-reported TPACK, the score of attitudes toward ICT, and ICT skills increased in both groups. However, the blended support condition reported a higher increase in the participants' technological knowledge (TK), technological pedagogical knowledge (TPK), their attitude toward ICT as a tool for instruction and productivity, and ICT enjoyment. This indicated that students perceived the blended condition for supporting design teams as a more desirable method for enhancing their development of TPACK.
\end{abstract}

\section{Introduction}

How to integrate ICT into teacher preparation programs is drawing educators' attention. They recognise that teaching ICT skills alone does not serve pre-service teachers well, because they learn how to operate ICT-related tools without being able to use them effectively to promote students' learning (Graham et al., 2009). To be an ICT-integrating teacher means going beyond ICT skills, and developing an understanding of the complex relationships between pedagogy, content and ICT (Hughes, 2005; Keating \& Evans, 2001; Lundeberg, Bergland, Klyczek \& Hoffman, 2003; Margerum-Leys \& Marx, 2002; Niess, 2005; Zhao, 2003). Hence, a teacher preparation program should provide students with the knowledge, skills, and experience needed to integrate ICT effectively in their future practice, taking into account the interactions between pedagogy, content and ICT.

Mishra and Koehler (2006) introduced Technological Pedagogical Content Knowledge (TPACK) as a framework to understand and describe the kinds of knowledge needed by a teacher for effective ICT integration. The main bodies of knowledge in the TPACK framework are: content knowledge (CK), pedagogical knowledge (PK), and 
technological knowledge (TK). Besides these main bodies of knowledge, the TPACK framework stresses the importance of the interactions between these bodies of knowledge. These include pedagogical content knowledge (PCK) as addressed by Shulman (1987), technological content knowledge (TCK) referring to how ICT and content influence each other, technological pedagogical knowledge (TPK) addressing how pedagogies change while using ICT, and technological pedagogical content knowledge (TPACK), which is the knowledge that emerges from interactions among the three knowledge domains (Koehler \& Mishra, 2008).

Koehler, Mishra and Yahya (2007) suggested that teachers need to work collaboratively in Design Teams (DTs) in order to develop ICT solutions for authentic educational problems. This approach is known as Learning Technology by Design. In DTs, teachers develop flexible ways of thinking and rethinking about ICT, design, and learning that helps the development of TPACK. Since the main objective of any TPACK intervention is to prepare teachers to become ICT-integrating teachers, teachers' skills and attitudes toward ICT also need to be taken into account, because research has shown that skills and a positive attitude are key factors in the likelihood that a teacher will start using ICT in education (Albirini, 2006; Christensen \& Knezek 2008; Mumtaz, 2000; Tearle, 2003).

The development of pre-service teachers' TPACK is a main concern of the science teacher preparation program at the Public Authority of Applied Education and Training (PAAET) in Kuwait. The science teacher preparation program is a four-year program that prepares female teachers as primary science teachers. Students spend three and a half years (i.e., seven semesters) in the college learning theoretical knowledge, while the last semester is devoted to in-school training (Almodaires, 2009). During their in-school training, the students are obliged to take the educational seminar course. The idea behind the educational seminar course is to train pre-service teachers to find solutions for educational problems they face during their in-school training and their future teaching practices. It is within the educational seminar course that the pre-service teachers become acquainted with TPACK.

In a previous study on TPACK development at the science teacher program at PAAET, pre-service science teachers worked in DTs and were coached by technology, pedagogy, and content experts, to find an ICT solution for a real educational problem (Alayyar, Fisser \& Voogt, 2011). The findings of this study showed that pre-service teachers reported higher gains in different knowledge domains related to TPACK. However, in relation to CK, there was no significant difference. In the DTs pre-service teachers were able to develop an ICT-enhanced activity and integrate it into their lesson plan.

The pre-service teachers appreciated the support that was given to them. However, they also indicated that they would like to have more flexibility in relation to time and accessibility of the support - i.e., an environment that could be accessed any time anywhere, available in the Arabic language. The pre-service science teachers also mentioned their needs which they liked having integrated in the support environment. These needs were related to the technological aspects of the TPACK framework, such as tutorials on different ICT applications, designing and developing web-pages, providing examples on how to use ICT in student-centred classes, how to meet with experts online to discuss topics related to the science content, and providing authentic examples on using ICT in science education. 
The pre-service teachers also asked for a communication workplace by which DTs could share and discuss their work during their design process (Alayyar, Fisser \& Voogt, 2011). The experts who coached the students indicated that the face to face support they provided to the DTs during the course was essential in directing students' thinking toward TPACK and the relationships and interactions among different knowledge domains related to the TPACK framework, to aid in TPACK development. However, they also acknowledged that supporting the DTs face to face is time consuming.

This study explores the potential of blended support for learning as an efficient way to support the DTs, and tries to confirm the findings from a previous study (Alayyar, Fisser \& Voogt, 2011).

\section{Theoretical framework}

Flexibility related to time and delivery was indicated by the students and instructors as an important feature of an online environment to support the development of TPACK in DTs. Offering this kind of flexibility means that the students can learn whenever and wherever they want (Collis \& Moonen, 2001). However, students in the teacher preparation program at PAAET are accustomed to learning in a teacher-centred approach, where the teacher is the instructor (Alayyar, 2011; Alayyar, Fisser \& Voogt, submitted). An online environment that completely replaces the support of the expert instructors therefore may not be an effective strategy. In addition, as Graham (2006) reports, "many learners want the convenience offered by a distributed environment, yet do not want to sacrifice the social interaction and human touch of face to face learning" (Graham, 2006, p. 9). For this reason, this study explored a blended approach to support the DTs.

Littlejohn and Pegler (2007) argued that "blending is an art that has been practised by inspirational teachers for centuries. It centres on the integration of different types of resources and activities within a range of learning environments where learners can interact and build ideas" (p. 1). Masie (2002) indicated that blended learning is the use of two or more distinct methods, which may include combinations such as blending classroom instruction with online instruction, blending online instruction with access to a coach or faculty member, or blending simulations with structured courses. Blended learning is therefore not a single method of learning; nor is it a separate alternative to online learning or face to face learning methods (Hinkelman, 2005). Rather, it refers to any style of learning that combines different learning and delivery methods. In this study, we refer to blended support for learning as the combination of online and face to face support for learning.

Research on blended learning has shown that integrating online sessions with face to face activities can improve student interactions and satisfaction (Delacey \& Leonard, 2002; So \& Brush, 2008). Thomson (2003) reported that students who studied through a blended approach learned faster than those studying through online courses only. Graham, Allen and Ure (2003) found that blended learning was adopted for three main reasons: 1) improved pedagogy, 2) increased access or flexibility, and 3) cost effectiveness. In addition, some researchers argued that blended learning increases the level of active learning, peer to peer learning, and student-centred strategies (Collis, Bruijstens \& Veen, 2003). 
However, creating an effective blended learning environment is challenging and depends on the context. Among the challenges of blended learning is that first, it is time consuming for instructors, especially when transforming a traditional course into a blended one, while students expect more frequent feedback and interaction than in a face to face learning environment (Alebaikan \& Troudi, 2010; Graham et al., 2003). Second, it is difficult to find the right design for blended learning. Although blended learning can provide the best of all worlds, Graham (2006) warned that it can also provide the worst of all worlds if it is not carried out carefully. Neumeier (2005) concluded that the most important aim of blended learning design is to find the most effective and efficient combination of learning modes for the content, context, and objectives to create a learning environment that works as a whole. Among other challenges of blended learning are the culture of the educational institute or organisation in relation to comfort level for using ICT in education; the level of students' self-discipline; organisational and managerial support; students' responsiveness (Graham et. al., 2003); and societal norms and values (Alebaikan \& Troudi, 2010).

To design a blended learning environment that can overcome these challenges, Sale (2009) proposed that it is important to introduce ICT in a way that significantly enhances the design of the environment. This can be done by: 1) developing an awareness of the unique capabilities of the online environment and of ICT tools (i.e., access to online resources anytime and anywhere; hyperlink dynamic content; and social networking); and 2) identifying the pedagogical uses and affordances of ICT tools (e.g., Web2.0 tools enable synchronous and asynchronous communication media).

With the potential of blended learning in mind, an online support learning environment was developed. The online support learning environment in particular was expected to provide pre-service teachers with an in-depth experience of the potential benefits of ICT for student learning through demonstrating the potential of ICT as an effective tool to deliver parts of the content, supplementary resources, and support to learners; and through providing opportunities for ICT-supported social communication between team members, instructors, and different teams or classmates. It was expected that when pre-service teachers experience and practice working in the blended support for learning, they may move toward active learning, peer to peer learning, and student-centred strategies as described by Collis et al. (2003).

Through the online discussion forum, the pre-service teachers could post questions, answer questions, or reflect on discussions online, and thus could increase the participation rate in the discussion (Hsi, 1997) and foster deep thinking (Moore, 2002), because writing a message requires thoughtful thinking (Chen \& Looi, 2007). This in turn would lead to the development of complex perspectives on the addressed topic (Prain \& Lyons, 2000). Moreover, exploring the exemplary lesson materials available online would help the participants get a better understanding of ICT integration (Voogt, Almekinders, van den Akker \& Moonen, 2005), thereby helping in the development of TPACK. In addition, the pre-service teachers would become more independent learners. Access to the online environment with certain tasks and activities expected to increase the pre-service science teachers' attitude, competence, and confidence toward integrating ICT in teaching and learning would foster the development of TPACK. 


\section{The intervention}

In this study two kinds of support for learning were distinguished: human support and online support. The human support was provided by the three different experts on pedagogy, science content, and ICT, respectively. The online support was an online support portal in Moodle, an open source learning management system. The portal contained tutorials on how to use different kinds of software, examples of lesson plans that integrate ICT, a matrix of different ICT applications with suitable teaching methods, and examples or URL links on using ICT in science education. The portal also supported online expert support through a chat tool and offered a workplace for DTs to share documents, a discussion forum to reflect on what's going on in class, and to answer a weekly question. Next to this there were news messages, a calendar with upcoming events, and resources by which different students were asked to add links that they thought would be helpful.

The students participating in the study were divided into two conditions: Human Support (HS) and Blended Support (BS). In the HS condition, the experts supported the pre-service science teachers through face to face meetings during class time or during office hours, in relation to the process of designing the ICT lesson activities as a solution for the addressed pedagogical problem and to identify the best teaching strategy that could be used for the specific content with the appropriate ICT. In the BS condition, the DTs worked on their own during face to face meetings. The experts did not attend the class, unless there was a need from DTs. However, the DTs in the BS condition did have access to the online support environment.

The intervention took place during the spring semester of 2010. It lasted for 12 weeks, two hours per week; 78 students were registered in three sections of "Educational Seminar" course with two instructors. One instructor taught two groups: one group with the HS condition (22 students) and one group with the BS condition (31 students). The other instructor supervised another group in the BS condition (25 students), but was not giving any expert support. To introduce the pre-service students to TPACK and to form the DTs, a workshop was organised during the first four weeks for both groups.

During the last day of the workshop, students were asked to form a DT of three to four members. The DTs had to identify one topic (content related to the primary science curriculum), to be taught with ICT. Next, the researcher presented the online support environment for the groups that were assigned to participate in the BS condition. In the fifth week, both the HS and the BS group were asked to present their problem and the possible ICT solution for their peers and the experts. During this presentation, peers and experts reflected on the problem, the suggested ICT tool, and on the suggested pedagogy.

From week 5 through week 10, the instructors started the HS class by posing a weekly question or statement, which the students were asked to answer or reflect upon. The experts also joined the discussion. For the BS group, the question or statement was available online and the students needed to write their reflection in the discussion forum within the online environment. In this period, the DTs designed their solution for the addressed problem. For the HS group, the different experts attended the class to support the DTs during the design process. The BS groups were asked to use support available online and to meet with the experts only when needed. 
In week 11, the teams (HS and BS) were asked to present their solution to the experts and their peers. The teams were also asked to submit a CD containing their product with a paper describing their lesson plan, and their ICT integration plan explaining the role of the teacher and the student. The products of both groups were evaluated by the different experts. In the last week, all students were asked to answer the different questionnaires again and the HS group was asked to register in the online support environment and browse the site. Finally, interviews were conducted with the different teams.

\section{Problem statement and research questions}

This study is concerned with developing TPACK in pre-service teachers through working in DTs in the science teacher preparation program at PAAET. Based on the findings of a previous study (Alayyar, Fisser \& Voogt, submitted), we expected that supporting DTs by technological, pedagogical, and content experts would be helpful in the development of TPACK. The study wanted to test whether Human Support (HS) and Blended Support (BS) would have a different effect on pre-service teachers' development of TPACK .In addition we also aimed to confirm the findings of the previous study. This study seeks answers to the following research questions:

RQ1: Does working in Design Teams (DTs) develop pre-service teachers' knowledge, skills, and appropriate attitude needed for ICT integration?

RQ2: Does Human Support (HS) and Blended Support (BS) for learning have a different effect on pre-service teachers' development of TPACK, and on their attitude and skills related to ICT?

RQ3: How do pre-service teachers experience Blended Support (BS) for learning?

\section{Methodology}

\section{Participants}

The participants in this study were 78 pre-service teachers from the science teacher preparation program at PAAET. All of the students were registered in the "Educational Seminar" course with two instructors. The "Educational Seminar" course was accompanied by an in-school field training in the final semester of the educational program. All pre-service teachers were female, with an average age of 23 years. The participants had science either as their major or minor specialisation.

Almost all of the participants had a computer at home and about $96 \%$ of the participants indicated that they had an Internet connection at home. About $88 \%$ of the participants indicated that they had access to a computer at the department at PAAET and $73 \%$ of the participants indicated that they had Internet access at their department.

\section{Instruments}

Six different instruments were used in this study to measure the TPACK of the preservice teachers, their attitude toward ICT, their ICT-related skills, their experience with working in DTs, and the support they experienced. Table 1 shows a general overview of the different instruments used in this intervention and their purpose. 
Table 1: Overview of the different instruments used in this intervention

\begin{tabular}{|c|c|c|c|c|}
\hline Instruments & Purpose & RQ1 & RQ2 & RQ3 \\
\hline TPACK survey & Perceived TPACK development & $\mathrm{x}$ & $x$ & \\
\hline Attitude to ICT & Change in attitude to ICT & $\mathrm{x}$ & $\mathrm{x}$ & \\
\hline ICT skill $\mid$ ICT skill test & Change in ICT skills & $\mathrm{x}$ & $\mathrm{x}$ & \\
\hline ICT skill survey & Perceived change in ICT skills & $\mathrm{x}$ & $\mathrm{x}$ & \\
\hline Team logbook & Experience during the intervention & & & $\mathrm{x}$ \\
\hline Interview & Opinion of the BS & & & $\mathrm{x}$ \\
\hline $\begin{array}{l}\text { TPACK reflection } \\
\text { question }\end{array}$ & $\begin{array}{l}\text { Assess pre-service teachers: } \\
\bullet \text { understanding of TPACK } \\
\bullet \text { ability to apply TPACK framework in real life }\end{array}$ & & $\mathrm{x}$ & \\
\hline
\end{tabular}

The TPACK survey

The TPACK survey (Schmidt, Bran, Thompson, Koehler, Shin, \& Mishra, 2009) was used at the beginning and at the end of the intervention. This instrument uses a fivepoint Likert scale: 1) strongly disagree, 2) disagree, 3) neither agree nor disagree, 4) agree, and 5) strongly agree. The items included in this instrument measure pre-service teachers' self-assessments of the TPACK domains. The data from the survey was used to measure a perceived change in TPACK. The TPACK survey was translated to the Arabic language and reviewed by two educational technology experts. The Arabic instrument had a reliability of Cronbach's alpha between 0.72 and 0.86 on the different domains related to the TPACK framework of the instrument.

Attitude toward the ICT questionnaire

The attitude toward the ICT questionnaire to measure the attitude of the pre-service science teachers toward ICT was adapted from the Teachers' Attitude toward Computers Questionnaire (TAC) (Christensen \& Knezek, 1996). Six items were added to the TAC about the importance of ICT for learning. The adapted instrument was translated into the Arabic language and reviewed by two educational technology experts to ensure that the pre-service teachers fully understood the items. A factor analysis was conducted from which three scales emerged, which were labelled "Instructional and productivity tool", "Enjoyment", and "Avoidance and frustration". The number of items in each scale was 10,9, and 7, respectively, and the Cronbach's alpha were 0.82, 0.81 , and 0.88 , respectively.

The ICT skills tools

This instrument consists of two parts, the ICT skills test and the ICT skills questionnaire. The ICT skills test is a performance attainment scale used to measure the specific technological skills of the students at the start and at the end of the intervention. This test was designed by the researcher, and consists of six questions that measure different skills, such as dealing with the operating system and proficiency with the Microsoft Office suite, the Internet, Adobe Photoshop, and multimedia editing software. The test was reviewed by an educational technology expert and the reliability of the test was 0.85 . The ICT skills questionnaire is a selfreport measure and was created by combining two existing instruments: the national survey on information technology in teacher education by the Milken Exchange on Educational Technology (1999) and the Technology Proficiency Self-Assessment (TPSA) by Ropp (1999).

The researcher added some items to assess more advanced ICT skills, such as video conferencing, multimedia production, and simulations. This instrument was translated into the Arabic language and reviewed by two educational technology experts. The 
questionnaire has two main scales: "things participants can do on a computer at school" and "things participants feel confident to do on a computer". A factor analysis was conducted, from which two sub-scales emerged for each scale. From the first scale, subscales "basic skills" and "advanced skills" emerged. The number of items in each subscale was 7 and 3, and the Cronbach's alpha values were 0.86 and 0.87 , respectively. And from the second scale, subscales "multimedia tools" and "email and Internet" emerged. There were seven items in each subscale, and the Cronbach's alpha values were 0.83 and 0.84 , respectively.

The team logbook

At the end of the course, all teams were asked to submit a logbook that included the problems they faced during the design process, how these problems were solved, and from whom they got support and assistance.

Team interviews about blended support

A semi-structured interview for all the DTs was used to see how the BS was valued. This instrument was divided into two parts: the first part dealt with teams that experienced the BS. The questions for these teams were:

- Did you enjoy the blended approach during this course?

- Are you satisfied with the support during the blended approach during this course?

- Would you like to experience or use this approach again?

- Do you think that the blended approach was helpful? Why?

The second part of the instrument was for the teams that experienced HS. These teams were given permission to join the online environment at the end of the intervention. The questions for these teams were:

- What do you think of the online support environment?

- Would it have been helpful for you to use this kind of support during the course?

- Do you think this support can replace or blend with the human support that you experienced during this course?

TPACK reflection questions

At the end of the course, all students were asked to individually write an answer to two TPACK questions:

- What do we mean by TPACK?

- Describe the situation where you effectively could combine the content with ICT and a specific teaching approach in a classroom lesson. Please include in your answer a description of the content, objectives, target group, teaching approaches, ICT, and teachers' and students' roles in relation to ICT.

These questions were meant to assess pre-service students' understanding of TPACK and whether they could relate TPACK to their practice or experience during their inschool training, or within their preparation program.

\section{Data analysis}

Means and standard deviations were calculated for the TPACK survey, the attitude to ICT questionnaire, and the ICT skill tools test/survey. A $t$-test was used to compare 
the difference between the pre- and post-tests, and HS and BS group measurements. If the result of the $t$-test was significant, the effect size (Cohen's d) was calculated to get an indication of the magnitude of the effect. Cohen (1988) provided tentative benchmarks for the interpretation of effect sizes: $d=0.2$ small, $d=0.5$ medium, and $d=$ 0.8 large effect size. The data from the TPACK reflection questions were analysed by using the TPACK reflection rubric (Alayyar, Fisser \& Voogt, 2011).

The logbooks were analysed by grouping and labelling the content of the logs into three main categories: ICT tools (TK), problems/questions, and support provider. The ICT tools (TK) were subdivided into groups depending on their main functionalities. Questions or problems were clustered in design principles, content-related items, or pedagogy-related items. Support providers were categorised according to the person or resource that provided help to the students or teams. For each category it was calculated how often a certain aspect within that category was mentioned.

\section{Results}

\section{Development of knowledge, skills and attitude toward ICT while working in DTs}

The results of the TPACK survey are summarised in Table 2 . The results showed that the respondents reported significant gains on the different knowledge domains related to the TPACK framework, with a large effect size when comparing the post- and pretest data.

Table 2: Comparison of the pre-service teachers' perception of their TPACK

\begin{tabular}{|c|c|c|c|c|}
\hline Factor & $\begin{array}{c}\text { Pre } \\
\text { Mean (SD) }\end{array}$ & $\begin{array}{c}\text { Post } \\
\text { Mean (SD) }\end{array}$ & $\begin{array}{c}\text { P (level of } \\
\text { significance) }\end{array}$ & $\begin{array}{c}\text { Effect } \\
\text { size }\end{array}$ \\
\hline TK & $3.15(.536)$ & $3.81(.501)$ & 0.0001 & 1.3 \\
\hline CK & $3.54(.723)$ & $4.13(.372)$ & 0.0001 & 1.03 \\
\hline PK & $3.65(.488)$ & $4.28(.367)$ & 0.0001 & 1.5 \\
\hline PCK & $3.57(.692)$ & $4.24(.460)$ & 0.0001 & 1.1 \\
\hline TCK & $3.19(.649)$ & $4.24(.489)$ & 0.0001 & 1.9 \\
\hline TPK & $3.07(.403)$ & $4.24(.420)$ & 0.0001 & 2.8 \\
\hline TPACK & $3.00(.464)$ & $4.13(.403)$ & 0.0001 & 2.6 \\
\hline
\end{tabular}

Notes: 1 = Strongly disagree (SD); 2 = Disagree (D); 3 = Undecided (U); $4=$ Agree (A); $5=$ Strongly agree (SA)

Table 3 summarises the results for both the ICT skills test and the ICT survey. The results from the ICT skills test showed that there was a significant increase in students' scores, with a large effect size $(d=1.99)$. The results from the ICT skills survey showed that there was a significant difference at the end of the intervention on the scales related to the basic skills of ICT with a medium effect size $(d=0.60)$, and for "multimedia tools" and "email and Internet", with a large effect size for both $(\mathrm{d}=1.40$ and $\mathrm{d}=0.96$, respectively). However, no significant difference was found for the advanced ICT skills.

The participants' attitude toward ICT is summarised in Table 4. Results showed a significant increase for "ICT as a tool for instruction and productivity" and "enjoyment." The effect size was medium for enjoyment $(\mathrm{d}=0.60)$ and large for instructional and productivity tool $(\mathrm{d}=1.15)$. Anxiety and frustration had reduced significantly at the end of the intervention with a medium effect size $(d=0.52)$. 
Table 3: Comparison of pre-service teachers' pre and post ICT skills

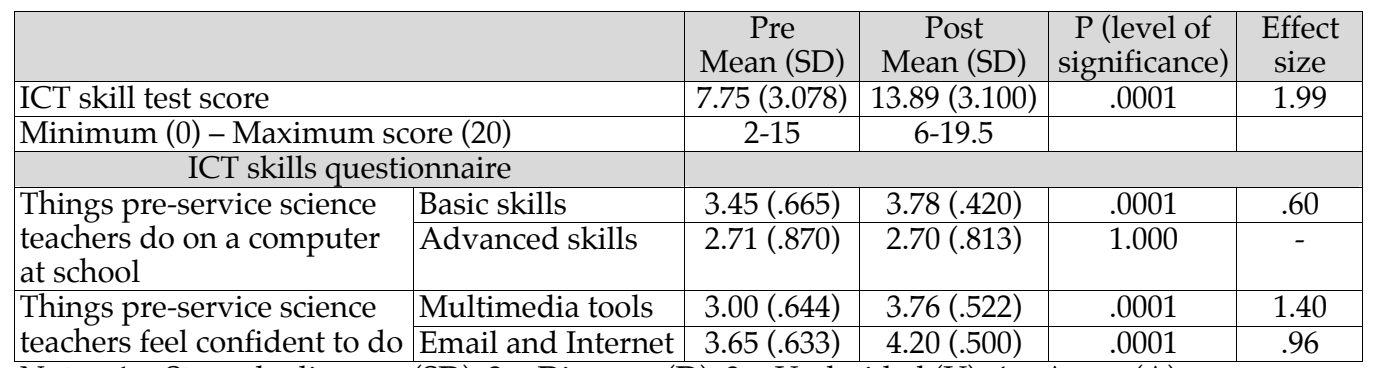

Notes: 1 = Strongly disagree (SD); 2 = Disagree (D); 3 = Undecided (U); 4 = Agree (A);

$5=$ Strongly agree (SA)

Table 4: Comparison of the pre-service teachers' pre and post attitude toward ICT

\begin{tabular}{|c|c|c|c|c|}
\hline Factors & \begin{tabular}{|c|} 
Pre \\
Mean (SD)
\end{tabular} & $\begin{array}{c}\text { Post } \\
\text { Mean (SD) }\end{array}$ & $\begin{array}{c}\mathrm{P} \text { (level of } \\
\text { significance) }\end{array}$ & $\begin{array}{c}\text { Effect } \\
\text { size }\end{array}$ \\
\hline Instructional and productivity tool & $4.00(.451)$ & $4.47(.362)$ & .0001 & 1.15 \\
\hline Enjoyment & $3.93(.478)$ & $4.22(.492)$ & .0001 & .60 \\
\hline Anxiety and frustration & $2.58(.769)$ & $2.21(.642)$ & .0001 & -.52 \\
\hline
\end{tabular}

\section{The difference between human support and blended support groups in relation to change in TPACK skills and attitude toward ICT}

The results of the growth in different knowledge related to TPACK for the HS condition and the BS condition are summarised in Table 5. The gains for the different knowledge domains for respondents in the BS condition was higher for all factors except PCK. However, only the gains in TK and TPK were significant $(\mathrm{p}=0.013$ and $\mathrm{p}$ $=0.024$, respectively), with a medium effect size $(\mathrm{d}=0.75$ and $\mathrm{d}=0.73$, respectively).

Table 5: Comparison of the change in TPACK (post - pre) in HS and BS groups

\begin{tabular}{|l|c|c|c|c|}
\hline \multicolumn{1}{|c|}{ Factor } & $\begin{array}{c}\text { HS } \\
\text { Mean (SD) }\end{array}$ & $\begin{array}{c}\text { BS } \\
\text { Mean (SD) }\end{array}$ & $\begin{array}{c}\text { P (level of } \\
\text { significance) }\end{array}$ & Effect size \\
\hline Change in TK & $.42(.435)$ & $.74(.418)$ & .013 & .75 \\
\hline Change in CK & $.54(.985)$ & $.61(.597)$ & .789 & \\
\hline Change in PK & $.55(.589)$ & $.65(.436)$ & .528 & \\
\hline Change in PCK & $.74(.806)$ & $.61(.728)$ & .544 & \\
\hline Change in TCK & $.84(.834)$ & $1.01(.684)$ & .259 & \\
\hline Change in TPK & $.88(.543)$ & $1.23(.407)$ & .024 & .73 \\
\hline Change in TPACK & $1.07(.605)$ & $1.13(.438)$ & .716 & \\
\hline
\end{tabular}

The results of the open questions on TPACK definition and examples are shown in Table 6. Participants in the BS condition were able to define the TPACK framework significantly better than the participants in the HS condition ( $p=0.0001)$ with a large effect size $(\mathrm{d}=1.03)$. Participants in the BS condition also scored significantly higher than the participants in the HS condition in their description of a situation where they can apply TPACK $(\mathrm{p}=0.0001)$, with a large effect size $(\mathrm{d}=1.5)$. 
Table 6: Comparison of TPACK reflection question for HS and BS groups

\begin{tabular}{|l|c|c|c|c|}
\hline \multicolumn{1}{|c|}{ Question } & $\begin{array}{c}\text { HS } \\
\text { Mean (SD) }\end{array}$ & $\begin{array}{c}\text { BS } \\
\text { Mean (SD) }\end{array}$ & $\begin{array}{c}\text { P (level of } \\
\text { significance) }\end{array}$ & Effect size \\
\hline TPACK definition & $48.4(21.35)$ & $70.1(20.83)$ & .0001 & 1.03 \\
\hline TPACK example & $47.9(19.77)$ & $75.1(17.69)$ & .0001 & 1.50 \\
\hline
\end{tabular}

Note: the score is out of 100

Table 7 shows a summary of the change in attitude related to ICT for the BS condition and the HS condition. Change in both factors, "instructional and productivity tool" and "enjoyment", were significant $(\mathrm{p}=0.001$ and $\mathrm{p}=0.04$, respectively) in favour of the BS condition with a large effect size $(\mathrm{d}=1.06)$ for instructional and productivity tool, and a medium effect size $(\mathrm{d}=0.63)$ for enjoyment.

Table 7: Comparison of the attitude toward ICT for HS and BS groups

\begin{tabular}{|l|c|c|c|c|}
\hline \multicolumn{1}{|c|}{ Factors } & $\begin{array}{c}\text { HS } \\
\text { Mean (SD) }\end{array}$ & $\begin{array}{c}\text { BS } \\
\text { Mean (SD) }\end{array}$ & $\begin{array}{c}\text { P (level of } \\
\text { significance) }\end{array}$ & $\begin{array}{c}\text { Effect } \\
\text { size }\end{array}$ \\
\hline Change in instructional and productivity tool & $.14(.406)$ & $.61(.475)$ & .001 & 1.06 \\
\hline Change in enjoyment & $.06(.431)$ & $.37(.552)$ & .04 & .63 \\
\hline Change in avoidance and frustration & $-.50(.515)$ & $-.34(.697)$ & .45 & - \\
\hline
\end{tabular}

No significant differences were found between both conditions in gains on the ICT skill test and ICT skill survey. The results are shown in Table 8.

Table 8: Summary of descriptive statistics for the score of ICT skill test for both groups

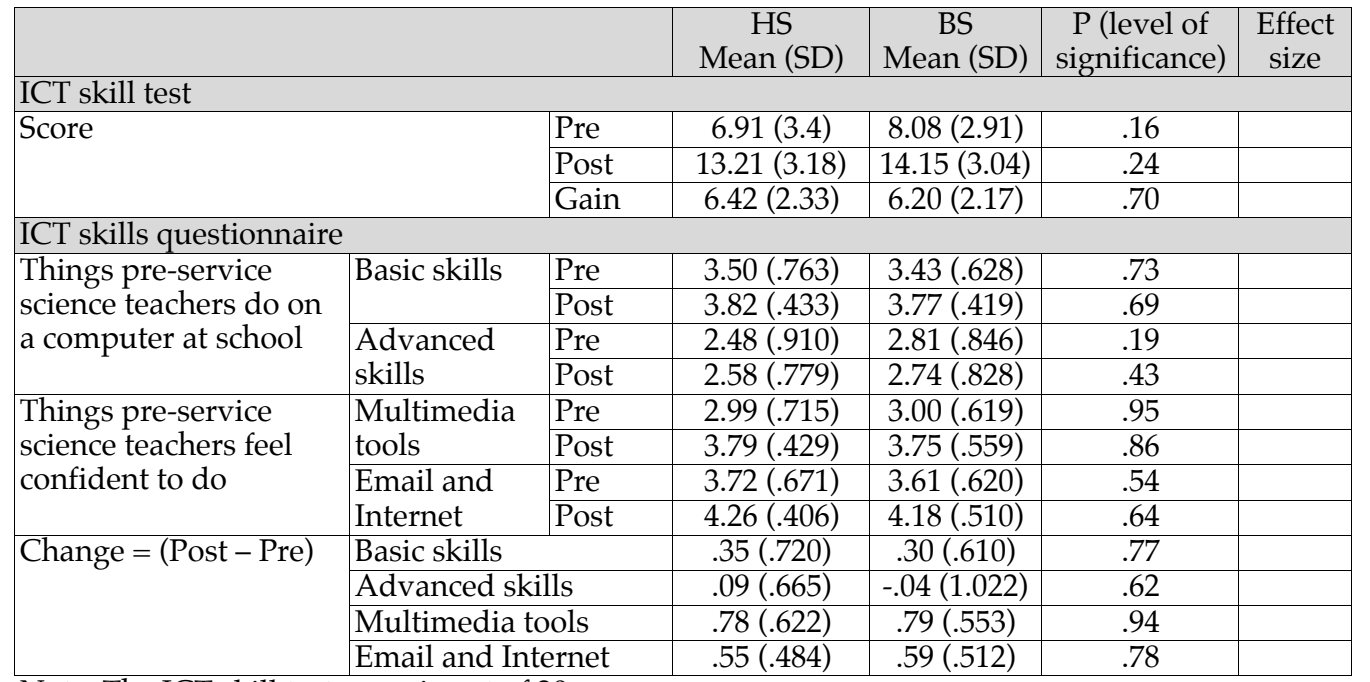

Note: The ICT skill test score is out of 20

\section{Blended support experience of the pre-service teachers}

From the teams' logbook, it was found that the BS condition group tried to solve its ICT-related problems directly by using the online support environment. Most of the teams in the BS condition asked to meet the experts about design principles, or about the progress of their product. The BS condition group rarely asked about ICT-related skills. In addition to the questions the BS condition was asking, the teams in the HS 
condition also asked questions about ICT-related technical skills. In general, the addressed problems of the teams were mainly about the technical aspect of the TPACK framework: TK, TPK, TCK, and TPACK, but were hardly related to other aspects of TPACK: PK, CK, and PCK, as was also found in the previous study (Alayyar, Fisser \& Voogt, 2011).

Looking to the results from the interview with the BS teams, all of the teams indicated that they enjoyed their experience with the BS approach, and would like to have this experience through the whole program. They found the online environment helpful and gave a number of reasons why. One team indicated that this kind of support saved them time and effort, as they did not need to wait until they could meet with the experts to ask for an explanation or solution. Another team argued that through this approach they became less dependent on the instructor. They could solve their problems directly whenever it arose at any place and time. Furthermore, different teams argued that through the BS condition, they learned about ICT tools while they were working and accessing the online support. Also, some teams indicated that providing examples of lesson plans that integrate ICT and the use of different ICT applications in the science classroom gave them a deeper understanding of how to integrate ICT in science education, and it gave them the opportunity to think differently about ICT for science education compared with the way they were using ICT in their daily life. They also addressed the importance of the discussion forums available through the site to share their ideas with their peers and different experts, for a deeper understanding of issues related to the design or the course.

When looking at the answers of the HS condition on the interview after visiting and exploring the online support environment, almost all HS teams were upset about not being able to access the online support environment during the intervention, and they indicated that if they were allowed to use it during the intervention, they would have gained higher results and their product would be better. They confirmed that this kind of support should be used with the availability of the HS at the same time and not alone, because they still needed the instructor to guide them in the face to face environment, as some teams clarified.

\section{Discussion}

The purpose of this study was to explore whether providing blended support is an efficient alternative to support the development of TPACK in the pre-service science teachers while working in DTs in the context of the science teacher preparation program at the Public Authority of Applied Education and Training in Kuwait. In addition, we wanted to confirm the findings from the previous study, that working in DTs to design an ICT-enhanced lesson is a promising way for the development of TPACK in pre-service science teachers.

This study did confirm the findings of our previous study (Alayyar, Fisser \& Voogt, 2011), that working in design teams had a positive effect on teachers' development of TPACK. We found that students perceive that working in DTs led to the development of all domains related to TPACK. In addition, we found that the pre-service teachers gained more ICT skills and developed a better attitude toward ICT. This indicates that the teachers became more ICT competent and probably also more confident in using ICT in their teaching. From these results, we conclude that working in DTs could indeed be a suitable approach to develop TPACK for effective ICT integration. Our 
findings are comparable to other studies that use an approach in which teachers work together to develop an ICT-enhanced solution for authentic pedagogical problems (e.g., Angeli \& Valanides, 2009; Gao, Tan, Wang, Wong \& Choy, 2011; Koehler, Mishra \& Yahya, 2007; Neo, 2005; Shin et al., 2009; So \& Kim, 2009).

Supporting DTs with appropriate guidance during the design process is important, especially when ICT integration and working in teams are new learning approaches, as is the case in this study. Both the human support and blended support conditions showed significant positive effects on teachers' attitudes, knowledge, and skills that are needed for ICT integration, leading to the conclusion that both the HS condition and the BS condition are successful alternatives for supporting pre-service teachers.

Under the blended support condition, the findings indicated even higher gains in attitudes towards ICT, technological knowledge, and technological pedagogical knowledge. No differences were found in anxiety and frustration toward computers, ICT skills (test and survey), and - except for TK and TPK - other aspects of TPACK. Compared to the HS group, the BS group's attitude toward the computer as an instructional and productivity tool, and their enjoyment of working with ICT tools were higher. This can be explained by the fact that the BS group had more flexible options to access online support whenever they needed it. The online environment also gave them the opportunity to explore and discuss the affordances and constraints of different ICT tools, and the pedagogical use of ICT during the available time more deeply, instead of only focusing on separate ICT skills. Similar findings were also found in the studies of Voogt, Almekinders, van den Akker and Moonen (2005), and Yang and Chen (2010).

Based on the results of our study, we can see that the pre-service teachers in the BS condition were satisfied with the kind of support they received. Mainly, they appreciated the combination of the support and guidance provided by the instructors and the flexibility of the online environment. The ability to access the online environment any time, any place, whenever they needed to, saved them time and effort while working in the DTs with their peers. The online tutorials, the different examples of lesson plans that integrate ICT, the different examples of ICT tools and their potential use in education that was available online, gave them the opportunity to explore different technological tools and suitable teaching methods, and to decide which ICT would best meet their needs. The online discussion forum was found to be very helpful, because the pre-service teachers could exchange their ideas and opinions and get instant feedback from team members, peers, or experts. The increase of communication, the exchange of ideas, and the depth of classroom discussions most likely enhanced their understanding of the topic addressed in class.

\section{Conclusions}

The findings from this study are relevant findings, especially in the Kuwaiti context, where traditional teaching methods with teacher-centred approaches are still predominant. Using technology in education already is an educational reform in this context, using a blended support approach is a second, and maybe even more challenging innovation. With regard to this context-specificity we would like to elaborate on some of the findings in relation to the blended support approach, but also in relation to the measurements that were used. 
The higher gain in TK in the BS group may be attributed to the fact that the participants from the BS condition were using ICT (the online support environment) while they were learning about ICT (i.e., learning by doing), which may have increased their confidence in their TK, compared to their peers in the HS condition. However, it is interesting that although the participants in the BS condition gained more in TK, no significant difference was found between the two groups in relation to their gain in ICT skills, as measured in the ICT skills test and the ICT skills survey. This may be due to the fact that the scores for TK were derived from the TPACK survey, which is a selfreported instrument that measures pre-service teachers' self-efficacy in TK. A closer inspection of the items that construct TK show that it measures a general understanding of technology (e.g., "I know about a lot of different technologies"), while the ICT skills survey measures how the pre-service teachers perceive their ability to use specific ICT applications (e.g., "I can edit video clips by using video editing software," and "I can animate an object to explain a phenomenon or process").

In addition, the ICT skills test measures pre-service teachers' ICT skills. This implies that the BS group had more confidence in its general understanding of technology compared to the HS group, but that the support offered (either blended or human) did not make a difference in their ICT skills, nor in their perceived ability to use specific ICT applications. One may wonder whether the TK scale in the TPACK survey is an adequate measure, if one intends to measure pre-service teachers' skills to use ICT in teaching and learning. Graham and his colleagues (2009) also had more concrete factors in relation to TK in their instruments to assess TPACK, such as "save an image from a website," "send an email with attachment," "create and edit digital video," and "use web2.0 technology". This shows that it is not yet very clear what kind of knowledge (declarative, procedural, or both) TK encompasses as a specific knowledge domain.

The BS condition seemed to be more effective related to the development of TPK. This may be because the online environment offered the participants in the BS condition experiences on how ICT could be used to deliver a part of the content or support to learners. This may have provided the participants a better idea about the potential of ICT for student learning, and it may have increased their confidence in their TPK (e.g., Szabo \& Schwartz, 2011; Voogt, Almekinders, van den Akker \& Moonen, 2005).

Although the participants in the BS condition did not have higher gains on TPACK (the integral measure) than their peers in the HS condition, they were able to define TPACK more accurately, and were better able to explain and reflect on their experiences about TPACK in the design and teaching process. This may be attributed to the online discussion forum, which invites learners to spend more time to think deeply before giving their answers (Moore, 2002), which in turn may lead to a deeper understanding of the addressed topic. We also know that written messages are often produced more thoughtfully than spoken messages in, for instance, a class discussion (Chen \& Looi, 2007). These findings show that measuring TPACK through selfreported questions does not necessarily show that teachers developed TPACK. However, if we consider the TPACK survey as a self-efficacy instrument, the findings do show that teachers' confidence in using ICT for teaching and learning has developed in both conditions.

In general, it seems that the TPACK framework cannot be assessed by one single instrument, as was also confirmed recently by, for instance, Tee and Lee (2011). Or as Doering, Scharber, Miller and Veletsianos (2009) concluded, "TPACK needs to be 
investigated from a number of complementary angles that contribute to a holistic assessment of how teachers teach with ICT". We therefore recommend developing valid and reliable instruments that measure pre-service teachers' TPACK through observable measures, e.g., by demonstrating their ability to integrate ICT in lesson plans or classroom practice.

In conclusion, the findings from this study not only confirm the findings from the previous study, but also provide a basis for applying the "Design Team" approach and the "Blended Support for Learning" approach to prepare pre-service teachers at PAAET for ICT integration. This is even more beneficial in relation to the e-learning strategy of the Ministry of Education in Kuwait (2008), which adopts the blended learning approach for implementation in public schools. Therefore, it is beneficial that pre-service teachers experience and practice blended learning before graduation. Both ICT integration in education and the student-centred approach through working in DTs are new strategies for learning at the science teacher preparation program at PAAET. However, when the pre-service teachers are provided with appropriate support and help during the intervention process, they will achieve the desired goals and will be better able to integrate ICT in their future teaching practice.

\section{References}

Alayyar, G. M. (2011). Developing pre-service teacher competencies for ICT integration through design teams. Thesis. University of Twente, Enschede. http: / / dx.doi.org/10.3990/1.9789036532341

Alayyar, G., Fisser, P. \& Voogt, J. (submitted). Attitude and competencies of pre-service teachers in Kuwait toward information and communication technology: Implications for ICT integration in teacher education.

Alayyar, G., Fisser, P. \& Voogt, J. (2011). Technology integration through design teams in science teacher preparation. International Journal of Learning Technology, 6(2), 125-145. http: / / dx.doi.org/10.1504/IJLT.2011.042645

Albirini, A. (2006). Teachers' attitudes toward information and communication technologies: The case of Syrian EFL teachers. Computers and Education, 47(4), 373-398. http: / / dx.doi.org/10.1016/j.compedu.2004.10.013

Alebaikan, R. \& Troudi, S. (2010). Online discussion in blended courses at Saudi universities. Procedia - Social and Behavioral Sciences, 2(2), 507-514. http: / / dx.doi.org/10.1016/j.sbspro.2010.03.054

Almodaires, A. (2009). Technology-supported reflection: Towards bridging the gap between theory and practice in teacher education. Unpublished doctoral dissertation, University of Twente, Enschede, The Netherlands. http:/ / doc.utwente.nl/67230/

Angeli, C. \& Valanides, N. (2009). Epistemological and methodological issues for the conceptualization, development, and assessment of ICT-TPCK: Advances in technological pedagogical content knowledge (TPCK). Computers $\mathcal{E}$ Education, 52(1), 154-168. http: / / dx.doi.org/10.1016/j.compedu.2008.07.006

Chen, W. \& Looi, C. (2007). Incorporating online discussion in face to face classroom learning: A new blended learning approach. Australasian Journal of Education Technology, 23(3), 307-326. http: / / www.ascilite.org.au/ajet/ajet23/chen.html

Christensen, R. \& Knezek, G. (1996). Constructing the Teachers' Attitudes toward Computers (TAC) questionnaire. ERIC Document Reproduction Service No. ED398244. http:/ / www.eric.ed.gov /ERICWebPortal/ contentdelivery / servlet/ERICServlet?accno=ED398244 
Christensen, R. \& Knezek, G. (2008). Self-report measures and findings for information technology attitudes and competencies. In J. Voogt \& G. Knezek (Eds.), International handbook of information technology in primary and secondary education (pp. 321-331). New York: Springer.

Cohen, J. (1988). Statistical power analysis for the behavioral sciences (2nd ed.). Hillsdale, NJ: Erlbaum.

Collis, B., Bruijstens, H. \& Van der Veen, J. K. (2003). Course redesign for blended learning: Modern optics for technical professionals. International Journal of Continuing Engineering Education and Lifelong Learning, 13(1/2), 22-38.

http: / / inderscience.metapress.com/ content/51g6t0kfqbgu678y/

Collis, B. \& Moonen, J. (2001). Flexible learning in a digital world: Experiences and expectations. London: Kogan Page.

DeLacey, B. J. \& Leonard, D. A. (2002). Case study on technology and distance in education at the Harvard Business School. Educational Technology and Society, 5(2), 13-28. http:/ / www.ifets.info/journals/5_2/delacey.html

Doering, A., Scharber, C., Miller, C. \& Veletsianos, G. (2009). GeoThentic: Designing and assessing with technology, pedagogy, and content knowledge. Contemporary Issues in Technology and Teacher Education, 9(3). http: / / www.citejournal.org/vol9/iss3/socialstudies/article1.cfm

Gao, P., Tan, S. C., Wang, L., Wong, A. \& Choy, D. (2011). Self reflection and preservice teachers' technological pedagogical knowledge: Promoting earlier adoption of student-centred pedagogies. Australasian Journal of Educational Technology, 27(6), 997-1013. http://www.ascilite.org.au/ajet/ajet27/gao.html

Graham, C. R., Burgoyne, N., Cantrell, P., Smith, L., St. Clair, L. \& Harris, R. (2009). TPACK development in science teaching: Measuring the TPACK confidence of inservice science teachers. TechTrends, 53(5), 70-79. http:/ / dx.doi.org/10.1007/s11528-009-0328-0

Graham, C. R. (2006). Blended learning systems: Definition, current trends, and future directions. In C. J. Bonk \& C. R. Graham (Eds.), The handbook of blended learning: Global perspectives, local design (pp. 3-21). San Francisco, CA: Pfeiffer.

Graham, C. R., Allen, S. \& Ure, D. (2003). Blended learning environments: A review of the research literature. Unpublished manuscript, Provo, UT.

Graham, C. R., Allen, S. \& Ure, D. (2005). Benefits and challenges of blended learning environments. In M. Khosrow-Pour (Ed.), Encyclopedia of information science and technology (pp. 253-259). Hershey, PA: Idea Group.

Hinkelman, D. (2005). Blended learning: Issues driving an end to laboratory-based CALL. JALT Hokkaido Journal, 9, 17-31. http: / / www.jalthokkaido.org/jh_journal/2005/Hinkelman.pdf

Hsi, S. (1997). Facilitating knowledge integration in science through electronic discussion: The multimedia forum kiosk. Unpublished doctoral dissertation, University of California, Berkeley. http: / / proquest.umi.com / pqdlink?did=736590651\&Fmt=7\&clientId=79356\&RQT=309\&VNa $\mathrm{me}=\mathrm{PQD}$

Hughes, J. (2005). The role of teacher knowledge and learning experiences in forming technology-integrated pedagogy. Journal of Technology and Teacher Education, 13(2), 277-302. http: / / www.editlib.org/p/26105 
Keating, T. \& Evans, E. (2001). Three computers in the back of the classroom: Pre-service teachers' conceptions of technology integration. Paper presented at the annual meeting of the American Educational Research Association, Seattle, WA.

Koehler, M. \& Mishra, P. (2008). Introducing TPCK. In AACTE (Ed.), Handbook of technological pedagogical content knowledge (TPCK) for educators (pp. 3-29). London: Routledge.

Koehler, M., Mishra, P. \& Yahya, K. (2007). Tracing the development of teacher knowledge in a design seminar: Integrating content, pedagogy and technology. Computers $\mathcal{E}$ Education, 49(3), 740-762. http:/ / dx.doi.org/10.1016/j.compedu.2005.11.012

Littlejohn, A. \& Pegler, C. (2007). Preparing for blended e-learning. London: Routledge.

Lundeberg, M., Bergland, M., Klyczek, K. \& Hoffman, D. (2003). Using action research to develop preservice teachers' confidence, knowledge and beliefs about technology. Journal of Interactive Online Learning, 1(4). http: / / www.ncolr.org/jiol/issues/pdf/1.4.5.pdf

Margerum-Leys, J. \& Marx, R. W. (2002). Teacher knowledge of educational technology: A case study of student/mentor teacher pairs. Journal of Educational Computing Research, 26(4), 427462. http:/ / dx.doi.org/10.2190/JXBR-2G0G-1E4T-7T4M (also at http:/ / www.eric.ed.gov/ ERICWebPortal / contentdelivery / servlet/ERICServlet?accno=ED442763)

Masie, E. (2002). Blended learning: The magic is in the mix. In A. Rossett (Ed.), The ASTD elearning handbook (pp. 58-63). New York: McGraw-Hill.

Milken Exchange on Educational Technology Report (1999). Will new teachers be prepared to teach in a digital age? A national survey on information technology in teacher education. [viewed 22 Jun 2009 at http:/ / www.milkenexchange.org/research/iste_results.html; not found 29 Sep 2012, see http: / / www.eric.ed.gov/ERICWebPortal/search/detailmini.jsp?_nfpb=true\&_\&ERIC ExtSearch_SearchValue_0=ED428072\&ERICExtSearch_SearchType_0=no\&accno=ED428072]

Ministry of Education (2008). The e-learning strategy (report). Kuwait.

Mishra, P. \& Koehler, M. (2006). Technological pedagogical content knowledge: A framework for teacher knowledge. Teachers College Record, 108(6), 1017-1054. http: / / www.tcrecord.org/ Content.asp?ContentID=12516

Moore, M. G. (2002). Editorial: What does research say about the learners using computermediated communication in distance learning? American Journal of Distance Education, 16(2), 61-64. http: / / dx.doi.org/10.1207/S15389286AJDE1602_1

Mumtaz, S. (2000). Factors affecting teachers' use of information and communications technology: A review of the literature. Journal of Information Technology for Teacher Education, 9(3), 319-341. http: / / dx.doi.org/10.1080/14759390000200096

Neo, M. (2005). Engaging students in group-based learning - A Malaysian perspective. Educational Technology \& Society, 8(4), 220-232. http:/ / www.ifets.info/journals/8_4/20.pdf

Neiss, M. L. (2005). Preparing teachers to teach science and mathematics with technology: Developing a technology pedagogical content knowledge. Teaching and Teacher Education, 21(5), 509-523. http: / / dx.doi.org/10.1016/j.tate.2005.03.006

Neumeier, P. (2005). A closer look at blended learning — parameters for designing a blended learning environment for language teaching and learning. ReCALL, 17(2), 163-178 http: / / dx.doi.org/10.1017/ S0958344005000224 
Ropp, M. (1999). Exploring individual characteristics associated with learning to use computers in pre-service teacher preparation. Journal of Research on Computing in Education, 31(4), 402424.

Sale, D. (2009). What is effective blended learning? [verified 29 Sep 2012] http: / / www.dennis sale.com/wp-content/uploads / 2009/03/what-is-effective-blended-learning2.doc

Schmidt, D., Baran, E., Thompson, A., Koehler, M. J., Shin, T. \& Mishra, P. (2009). Technological pedagogical content knowledge (TPACK): The development and validation of an assessment instrument for preservice teachers. Paper presented at the 2009 Annual Meeting of the American Educational Research Association. April 13-17, San Diego, California. http: / / mkoehler.educ.msu.edu / unprotected_readings / TPACK_Survey / Schmidt_et_al_Sur vey_v1.pdf

Shin, T., Koehler, M., Mishra, P., Schmidt, D., Baran, E. \& Thompson, A. (2009). Changing technological pedagogical content knowledge (TPACK) through course experiences. In Proceedings of Society for Information Technology and Teacher Education International Conference 2009 (pp. 4152-4159). http:/ / www.editlib.org/p/31309 (also at http: / / punya.educ.msu.edu/publications /Shin_et_al_SITE2009.pdf)

Shulman, L. (1987). Knowledge and teaching: Foundations of the new reform. Harvard Educational Review, 57(1), 1-23. http:/ / www.hepg.org/her/abstract/ 461

So, H. \& Brush, T. (2008). Student perceptions of collaborative learning, social presence and satisfaction in a blended learning environment: Relationships and critical factors. Computers E Education, 51(1), 318-336. http:/ / dx.doi.org/10.1016/j.compedu.2007.05.009

So, H. J. \& Kim, B. (2009). Learning about problem based learning: Student teachers integrating technology, pedagogy and content knowledge. Australasian Journal of Educational Technology, 25(1), 101-116. http:/ / www.ascilite.org.au/ajet/ajet25/so.html

Szabo, Z. \& Schwartz, J. (2011). Learning methods for teacher education: The use of online discussions to improve critical thinking. Technology, Pedagogy and Education, 20(1), 79-94. http: / / dx.doi.org/10.1080/1475939X.2010.534866

Tee, M. Y. \& Lee, S. S. (2011). From socialisation to internalisation: Cultivating technological pedagogical content knowledge through problem-based learning. Australasian Journal of Educational Technology, 27(1), 89-104. http:/ / www.ascilite.org.au/ajet/ ajet27/ tee.html

Tearle, P. (2003). ICT implementation: What makes the difference? British Journal of Educational Technology, 34(5), 567-583. http:/ / dx.doi.org/10.1046/j.0007-1013.2003.00351.x

Thomson \& NETg (2003). The next generation of corporate learning: Achieving the right blend. Retrieved from http: / / www.netg.com/NewsAndEvents/PressReleases/view.asp?PressID $=75 \#$ top [not found 29 Sep 2012]

Voogt, J., Almekinders, M., van den Akker, J. \& Moonen, B. (2005). A 'blended' in-service arrangement for classroom technology integration: Impacts on teachers and students. Computers in Human Behavior, 21(3), 523-539. http: / / dx.doi.org/10.1016/ j.chb.2004.10.003

Yang, H. H. \& Chen, P. (2010). Building teachers' TPACK through WebQuest development and blended learning process. Lecture Notes in Computer Science, Volume 6248, 71-81, http: / / dx.doi.org/10.1007/978-3-642-14657-2_8

Zhao, Y. (Ed.) (2003). What teachers should know about technology: Perspectives and practices. Greenwich, CT: Information Age. 
Authors: Ghaida M. Alayyar

Public Authority of Applied Education and Training, College of Basic Education, Department of Educational Technology, Kuwait City, Kuwait.

Email: g_alayyar@yahoo.com Web: http:/ / www.paaet.edu.kw/

Dr Petra Fisser (contact author)

Department of Curriculum Design \& Educational Innovation

Faculty of Behavioral Sciences, University of Twente

PO Box 217, 7500AE, Enschede, The Netherlands

Email: p.h.g.fisser@utwente.nl Web: http: / / users.gw.utwente.nl / fisser /

Dr Joke Voogt

Department of Curriculum Design \& Educational Innovation

Faculty of Behavioral Sciences, University of Twente

PO Box 217, 7500AE, Enschede, The Netherlands. Email: j.m.voogt@utwente.nl

Please cite as: Alayyar, G. M., Fisser, P. \& Voogt, J. (2012). Developing technological pedagogical content knowledge in pre-service science teachers: Support from blended learning. Australasian Journal of Educational Technology, 28(8), 1298-1316.

http:/ / www.ascilite.org.au/ajet/ajet28/alayyar.html 